\title{
СПЕЦИФІКА ПІДГОТОВКИ МАЙБУТНІХ УЧИТЕЛІВ АНГЛІЙСЬКОЇ МОВИ ДО ПРОФІЛЬНОГО НАВЧАННЯ СТАРШОКЛАСНИКІВ
}

\begin{abstract}
У статті теоретично розглядається проблема професійної підготовки майбутніх учителів англійської мови до профільного навчання старшокласників, щчо пов'язано з реформуванням системи вищої та загальної освіти (встановленням двох освітньо-кваліфікаційних рівнів бакалавра, магістра та впровадженням допрофільного та профільного навчання в основній і старшій школі). Проаналізовано необхідність пошуку нових шляхів інтенсифікаиії використання нових технологій навчання іноземної мови за умов упровадження Нової української школи та реалізації спільного проекту Міністерства освіти і науки України та Британської ради в Україні “Шкільний учитель нового покоління”.

У роботі проаналізовано теоретичні засади професійної підготовки майбутніх учителів англійської мови до профільного навчання старшокласників. Зроблено дефінітивний аналіз ключових понять: "підготовка”, "професійна підготовка", "професійна підготовка майбутнього учителя англійської мови”, "готовність майбутнього вчителя англійської мови до профільного навчання старшокласників". Проаналізовано сучасний стан професійної підготовки майбутніх педагогів до профільного навчання старшокласників у закладах вищої освіти. Виявлено різні підходи до визначення поняття “професійна підготовка", з'ясований зміст та основні принципи підготовки майбутнього вчителя англійської мови.

Виокремлено та схарактеризовано аксіологічно-мотивачійний, когнітивний, праксеологічний, професійно-особистісний, творчий і рефлексивний критерії, визначено ӥхні показники, на основі яких констатовано рівні. Унаслідок аналізу філософської, психологічної, педагогічної, методичної літератури, сучасного стану професійної підготовки майбутніх учителів англійської мови до профільного навчання старшокласників осмислено практичний педагогічний досвід закладів вищої освіти.

Окреслено основні тендениії у галузі вищьої педагогічної іншомовної освіти та вимоги до рівня професійної підготовки сучасного вчителя англійської мови до профільного навчання старшокласників. Обтрунтовано специфіку фахової підготовки майбутніх педагогів з урахуванням традиџій і позитивного досвіду організації навчально-виховного проиесу.

Ключові слова: професійна підготовка, учитель англійської мови, готовність, профільне навчання.
\end{abstract}

Сучасні тенденції європеїзації іншомовної освіти в Україні спрямовані на оновлення цілей і змісту навчання та вивчення іноземних мов у закладах середньої та вищої освіти, що висуває високі вимоги до підготовки учителів іноземних мов нової генерації, професійно готових здійснювати освітній процес за умов плюрилінгвізму і полілогу культур.

Одним із пріоритетних напрямів сучасної освіти в Україні є профілізація ії змісту у старшій школі. Профільне навчання має найбільшою мірою враховувати інтереси, нахили та здібності, можливості кожного школяра, у т. ч. з особливими освітніми потребами, у контексті соціального та професійного самовизначення і відповідності вимогам сучасного ринку праці. Такий підхід до організації освіти старшокласників не лише найповніше реалізує принцип особистісно орієнтованого навчання, а й дає змогу створити найоптимальніші умови для їхнього професійного самовизначення та подальшої самореалізації [7, с. 2].

Метою статті $\epsilon$ розгляд проблем професійної підготовки майбутніх учителів англійської мови до профільного навчання старшокласників.

Теоретичною базою впровадження профільного навчання є Закони України "Про освіту”, “Про загальну середню освіту”, Концепції профільного навчання у старшій школі, Державному стандарті базової і повної загальної середньої освіти та інших нормативно-правових документах. Основні теоретичні напрацювання вітчизняних і зарубіжних учених з урахуванням практичного досвіду в організації навчання старшокласників утілено в Концепції профільного навчання у старшій школі.

У Концепції профільного навчання у старшій школі одним із пріоритетних напрямів освітньої політики визначено створення системи профільного навчання у 10-11 класах загальноосвітніх навчальних закладів (3Н3).

Основними цілями запровадження профільного навчання є:

- забезпечення профільного (розширеного) вивчення окремих навчальних предметів згідно 3 програмами загальної середньої освіти;

- створення умов для істотної диференціації змісту навчання старшокласників із широкими та гнучкими можливостями побудови ними індивідуальних освітніх програм;

- сприяння встановленню рівного доступу до повноцінної освіти різним категоріям учнів відповідно до їхніх здібностей, індивідуальних нахилів і потреб;

- розширення можливостей соціалізації школярів, забезпечення наступності між загальною і професійною освітою, у т. ч. ефективнішої підготовки випускників школи до засвоєння програм вищої професійної освіти;

- виховання особистості, здатної до самореалізації, професійного зростання та мобільності за умов реформування сучасного суспільства. Профільне навчання IM є цілеспрямованою підготовкою учнів до 
подальшої навчальної або професійної діяльності, пов’язаної з використанням ІМ як об'єкта майбутньої спеціальності або як засобу професійної комунікації [7].

До основних завдань організації профільного навчання дослідники О. Кизим, С. Кропив'янська, С. Чистякова відносять такі: розкриття ролі шкільних предметів для розуміння структури професій; інтеграція шкільних навчальних предметів в актуальне знання, необхідне для ефективної трудової діяльності; надання змоги старшим школярам здійснювати різні спроби в системах “людина - техніка”, “людина - природа”, “людина - знак”, “людина - образ”, “людина - людина” і формування уявлення про свої можливості та уподобання; здійснення діагностичної функції, що дозволить за допомогою спостережень, тестів, анкетування, інтерв'ювання визначити динаміку розвитку особистості, зокрема функціональної грамотності, технологічних вмінь, інтелектуальної та вольової підготовленості; формування установки на ефективну працю й успішну професійну кар'єру; сприяння проєктуванню учнями своїх життєвих і професійних планів, ідеалів майбутньої професії та можливих моделей досягнення високої кваліфікації в ній [13, с. 101-108].

Дослідники висловлюють думку, що реалізація однією з основних функцій профільного навчання старшокласників є якомога повніше задоволення їхніх пізнавальних інтересів та освітніх потреб, зумовлених їх подальшими життєвими планами й орієнтацією на майбутню професію на основі надання учням можливості вільного вибору змісту навчання [12, с. 6].

Отже, у загальному вигляді профільне навчання визначається:

- по-перше, як процес, спрямований на життєву самоідентифікацію та професійне самовизначення старшокласників; диференційований за цілями та змістом навчання, у якому враховуються насамперед здібності, запити та професійні орієнтації старшокласників з урахуванням замовлення суспільства;

- по-друге, як підхід, який забезпечить поглиблене вивчення окремих дисциплін і навчальних напрямів, програми та стандарти повної середньої освіти, професійно диференціює зміст освіти та сприяє забезпеченню рівного доступу до якісної освіти;

- по-третє, як форма організації навчального процесу, спрямована на забезпечення особистісно орієнтованого освітнього процесу;

- по-четверте, як засіб індивідуалізації навчання, коли внаслідок змін у цілях, структурі, змісті та формах освітнього процесу повніше враховуються інтереси, здібності та схильності учнів, а також їхні професійні інтереси та наміри щодо продовження освіти.

Науково-теоретичний аналіз підготовки майбутніх учителів англійської мови до профільного навчання неможливий без глибокого системного вивчення детермінант, відсутність орієнтації у яких негативним чином позначається на готовності студентів до викладання у старшій школі. Тому логічним напрямом підготовки майбутніх учителів до профільного навчання є для нас аналіз профілізації старшої школи як цілісної педагогічної системи.

Професійна підготовка вчителя англійської мови за умов впровадження ідей нової української школи, що полягають у переході від трансляційної педагогіки до смислової, від авторитаризму до педагогічної кооперації, концептуально переосмислюється, і це пов’язано зі зміною методологічних основ освіти загалом.

Дотримання Болонських принципів, зокрема впровадження двоциклового навчання та освітніх і кваліфікаційних ступенів (бакалавра і магістра), є гарантією підготовки саме таких учителів. У Галузевому стандарті вищої освіти, освітньо-кваліфікаційної характеристики бакалавра за кваліфікацією вчителя німецької, англійської мов і зарубіжної літератури відображено вимоги до компетентності та соціально важливих якостей сучасного вчителя іноземних мов, ключовими серед яких є оволодіння системою сучасних лінгвокультурологічних знань, специфікою мовних картин світу, вміння використовувати іноземну мову для розвитку інтелекту та впливу на емоційну й пізнавальну сфери особистості учня, окреслення шляхів формування інтелектуальної й емоційної сфер особистості учня, вміння аналізувати досвід роботи, здійснювати самоконтроль, самооцінку, саморегуляцію, виділяти та переборювати недоліки у професійній діяльності [4].

Як зазначає Г. Бойко, формування готовності студентів до професійної діяльності передбачає виконання комплексу навчальних заходів, які мають забезпечити майбутнім учителям достатній рівень майстерності на основі засвоєння професійних знань:

- основних положень загальнодержавної політики у галузі шкільної освіти, у т. ч. 3 навчання іноземних мов;

- комунікативної компетенції, основними компонентами якої є мовна (лінгвістична), мовленнєва та соціокультурна компетенції;

- змісту й особливостей усіх компонентів навчання іноземної мови: цілей, методів, засобів тощо;

- психологічних особливостей учня, сфер його інтересів і задатків;

- змісту програми з навчання іноземних мов та інших нормативних документів;

- основних положень дидактико-методичної концепції, на якій побудований зміст підручника;

- основних вимог, які визначає суспільство до особистості сучасного вчителя, у т. ч. рівня його професійної майстерності [2].

Парадигмальні перетворення у шкільній освіті об'єктивно потребують нових підходів до підготовки майбутнього вчителя, результатом якої є сформованість професійної компетентності як необхідної умови освітньої діяльності, саморозвитку і самовдосконалення педагога. 
На будь-якому етапі формування професійної компетентності майбутнього вчителя англійської мови передбачає такі компоненти: “мотиваційно-цільовий (наявність мотиву досягнення мети, інтересу та готовності до професійної діяльності); когнітивний (наявність відповідних знань, умінь і здатності використання інформаційної техніки); операційно-діяльнісний (ефективність інформаційної діяльності із застосуванням інформаційних технологій); рефлексивний (готовність до пошуку вирішення проблем, творчого потенціалу особистості учня" [10, с. 18].

Так, майбутній учитель англійської мови повинен володіти теорією профільного навчання, що може, на наш погляд, містити в собі: глибоке знання основ освітньої галузі; психолого-вікових особливостей учнів старшої школи; знань про мотивацію творчої діяльності; уявлень про особливості емпіричного і теоретичного способів абстрагування й узагальнення та про структуру профільної пізнавальної діяльності старшокласників.

Отже, резюмуючи зазначене вище, ми зробили висновок, що майбутній учитель англійської мови профільної старшої школи повинен володіти трьома підсистемами впровадження форм і методів профільного навчання: викладенням змісту профільного навчального матеріалу, організацією комунікації “учитель учень", забезпеченням пізнавальної мотивації учнів до вивчення англійської мови.

Професійна підготовка майбутнього вчителя англійської мови до профільного навчання старшокласників на основі діяльнісного підходу передбачає: особистісно-професійне становлення студента, що становить цілісну сукупність його освітніх професійних цінностей; спосіб навчальної діяльності; прояв творчості у навчальному процесі; специфічний спосіб самореалізації, самовизначення і соціальної самоактуалізації (тобто навчання студентів відбувається за умов індивідуально орієнтованого підходу, за якого студент займає позицію самоуправління своєю навчально-пізнавальною діяльністю з урахуванням власного особистісного досвіду).

Студент сам встановлює індивідуальний освітній “вектор” власного професійного розвитку у контексті підготовки до роботи у старшій профільній школі. Нові, порівняно із традиційною освітою, завдання розвитку особистісно-інтелектуальних ресурсів учнів передбачають співтворчість учня і вчителя у проєктуванні змісту профільної освіти з метою забезпечення особистісного ставлення учня до вивчення англійської мови.

Таким чином, викладання дисциплін педагогічного циклу повинно здійснюватися як супровід і забезпечення професійного розвитку і саморозвитку майбутнього вчителя англійської мови через організацію різних видів як педагогічної, так і інших видів діяльності. Сучасна концепція педагогічної підготовки майбутнього вчителя іноземних мов передбачає зміни іiі пріоритетів: 1. Специфічні цілі: актуалізація і розвиток особистісних і суб'єктних функцій індивіда. 2. Зміст, у якому освітній стандарт органічно поєднується з особистісним досвідом того, кого навчають. 3. Технології, що забезпечують затребуваність особистісних функцій і особистісного рівня самореалізації індивіда.

Центральним положенням особистісного підходу є новий погляд на особистість студента і викладача 3ВО, який включає такі основні позиції: особистість студента є унікальним явищем, тому вона заслуговує на повагу (навіть якщо не є зразковою); особистість як студента, так і викладача, ії професійний розвиток є метою педагогічної системи університету; студент є не об'єктом, а суб'єктом психолого-педагогічної підготовки.

Провідною ідеєю при переосмисленні педагогічної підготовки є ідея активної ролі студента в розвитку його особистісних і професійних здібностей і якостей, тобто примат “суб’єктності”, високий рівень розвитку суб’єктивного контролю. Педагогічна підготовка повинна бути більшою мірою розвиваючою, саморозвиваючою і персоналізованою, а ії реалізація повинна забезпечувати вільний стабільний професійний розвиток майбутнього вчителя. Програми з дисциплін педагогічного циклу повинні мати розвиваючий характер, а для цього вони повинні: бути спрямовані на максимальне задоволення інтелектуальних, духовних і професійних запитів як студента, так і викладача; бути орієнтовані на розвиток їхніх педагогічних здібностей і педагогічного мислення; формувати педагогічну направленість особистості; враховувати особливості впливу акцентуацій характеру студента на продуктивність майбутньої професійної діяльності.

Таким чином, викладання дисциплін педагогічного циклу повинно здійснюватися як супровід і забезпечення професійного розвитку і саморозвитку майбутнього вчителя через організацію різних видів як педагогічної, так й інших видів діяльності. Аби встановити особливості формування професійно-педагогічної спрямованості майбутнього вчителя іноземних мов, необхідно з'ясувати особливості фахової підготовки майбутнього вчителя англійської мови [5, с. 27-28].

Становлення професійної позиції майбутнього вчителя іноземної мови засобами формування рефлексії, самооцінки й самосвідомості забезпечуються виконанням у професійно-педагогічній підготовці цілісної системи трьох принципів: рефлексивності, інтерактивності та проєктного підходу. Якщо виконання принципу рефлексивності забезпечує осмислення педагогічних цінностей і професійної діяльності, наділення їх власними смислами, інтерактивності (співвіднесення цих смислів зі світом соціальних значень і цінностей культури), то проєктний підхід забезпечує зворотний до осмислення процес - усвідомлення смислів [8].

Зміст професійної підготовки майбутніх учителів іноземних мов визначають Рекомендації Ради Свропи, конкретизуючи знання і вміння, які потрібно розвивати у користувачів мови для забезпечення ефективного спілкування у крос-культурному контексті, та пропонуючи комунікативні педагогічні завдання для активного залучення учнів до осмисленої комунікації на кожному ступені навчання [6]. 
Формування необхідного і достатнього рівня професійної компетенції майбутнього вчителя іноземної мови засобами визначення цілей, врахування специфіки вирішення навчальних завдань щодо формування загальної та комунікативної компетенцій учнів засобами вдосконалення володіння видами мовленнєвої діяльності у конкретній сфері спілкування є найважливішим завданням професійної підготовки студентів у мовному закладі вищої освіти.

Відповідно до цього зміст профільного навчання має бути спрямований на формування в учнів орієнтовних ключових компетентностей, що визначають успішну самореалізацію за умов постійно змінюваного суспільств, таких яка: самостійні рефлексивні дії; адекватне використання інструментарію (знарядь праці, технологій, мисленнєвих прийомів) для вирішення проблем; робота в колективі, співробітництво; творче і критичне мислення.

Важливим компонентом професійної компетенції майбутнього вчителя іноземних мов є професійні знання з педагогіки, психології, методики викладання іноземних мов, прикладної лінгвістики та вміння їх практичного використання у практичній педагогічній діяльності в закладі загальної середньої освіти, визначені галузевим стандартом вищої освіти.

Отже, професійна підготовка майбутніх учителів англійської мови потребує, крім засвоєння теоретичних знань, формування практичних професійних умінь застосування сучасних інноваційних технологій навчання учнів. Важливо зазначити, що у концепції Оксфордського університету базової підготовки вчителя акцентується увага на вирішенні фундаментальної проблеми взаємозв' язку теорії та практики: критичного вивчення, вдосконалення й експериментального використання практичних педагогічних ідей, різноманітної теоретичної та науково-дослідної літератури, тобто “практичне теоретизування" $[11$, c. $580-581]$.

Моделюючи зміст і структуру професійної діяльності майбутнього вчителя іноземної мови, Є. Пассов визначив вісім видів умінь, на розвиток яких слід спрямувати процес професійної підготовки в закладах вищої освіти: “проєктувальні вміння; адаптаційні вміння; організаційні вміння; мотиваційні вміння; комунікативні вміння; уміння контролю і самоконтролю; пізнавальні вміння” [9, с. 14].

Отже, сформованість зазначених вище вмінь майбутнього вчителя англійської мови забезпечує його загальнометодичну компетентність, що дозволить йому працювати як у різних типах 3ВО, так i на різних рівнях навчання закладів загальної середньої освіти - початковому, базовому і профільному.

Завершальним етапом у професійній підготовці майбутнього вчителя IM до профільного навчання старшокласників $є$ процес оволодіння професійною компетенцією зокрема: набуття професійних знань про особливості організації освітнього процесу з IM на старшому ступені навчання: послідовне здійснення комунікативно-пізнавального навчання, використання прийомів особистісно-орієнтованого оволодіння іншомовною комунікативною компетенцією на рівні В1+; цілеспрямована реалізація принципу професійної спрямованості навчання IM, орієнтована на використання IM у майбутній практичній діяльності старшокласників, активне застосування індивідуальних і групових форм самостійної роботи.

Проте в межах професійної підготовки вчителя іноземних мов навчальні технології як засіб побудови освітнього процесу та засвоєння конкретного навчального матеріалу варіюються залежно від форми навчання.

До провідних форм професійної підготовки у закладі вищої освіти належить лекція, яка не лише вирішує дидактичне завдання з ознайомлення студентів з основним змістом, принципами, закономірностями, головними ідеями навчального матеріалу, а й стимулює їх самостійну роботу [3, с. 99].

Висновки. Отже, технологічне забезпечення процесу професійної підготовки майбутнього вчителя англійської мови до профільного навчання старшокласників у контексті європейських вимог виявляє низку загальних тенденцій, зокрема: визначення нових цілей і змісту навчання, використання інноваційних навчальних технологій, розвиток індивідуальних, когнітивних стилів студентів, здійснення адекватного контролю за рівнем сформованості професійних знань і умінь.

Підводячи підсумок розгляду вищезгаданих понять із позицій інноваційних підходів до підготовки майбутніх учителів англійської мови, ми можемо зробити такі висновки.

Специфіка профілізації старшої школи висуває нові, підвищені вимоги до професійного рівня майбутнього вчителя англійської мови:

- забезпечення варіативності й особистісної орієнтації освітнього процесу, проєктування індивідуальних освітніх траєкторій;

- практичну орієнтацію освітнього процесу із введенням інтерактивних діяльнісних компонентів (засвоєння проєктно-дослідницьких і комунікативних методів);

- завершення профільного самовизначення старшокласників і формування ключових компетентностей, необхідних для продовження освіти у відповідній сфері професійної освіти.

Однією із провідних ідей підготовки майбутніх учителів англійської мови до профільного навчання старшокласників є усвідомлення значущості власної педагогічної діяльності у контексті профільного навчання та практичного впровадження набутих професійних знань, умінь і навичок у педагогічній практиці та майбутній професійній діяльності у сучасній школі. 


\section{Використана література:}

1. Бідюк Н. М. Організаційно-дидактичні засади професійної підготовки майбутніх учителів старшої школи США. Науковий вісник Ужгородського національного університету. Серія "Педагогіка, соиіальна робота". Вип. 21. С. 24-26.

2. Бойко Г. Формування професійної компетенції вчителів іноземних мов початкової школи. URL: http://oldconf.neasmo.org.ua/ node/3029.

3. Вітвицька С. С. Основи педагогіки вищої школи : методичний посібник для студентів магістратури. Житомир : Житомир. пед. ун-т, 2003. 232 с.

4. Галузевий стандарт вищої освіти. URL: https://mon.gov.ua/ua/osvita/visha-osvita/naukovo-metodichna-rada-ministerstvaosviti-i-nauki-ukrayini/zatverdzheni-standarti-vishoyi-osviti.

5. Гапоненко Л. П. Імітаційно-ігровий підхід у формуванні готовності студентів до іншомовного спілкування. Науковий вісник Південноукраӥнського державного педагогічного університету ім. К. Д. Уиинського. 2002. Вип. 4-5. С. 53-56.

6. Загальноєвропейські Рекомендації з мовної освіти: вивчення, викладання, оцінювання / наук. ред. С. Ю. Ніколаєва. Київ : Ленвіт, 2003. 273 с.

7. Концепція профільного навчання в старшій школі, затверджена наказом Міністерства освіти і науки від 21.10.2013p. № 1456. URL: https://mon.gov.ua/storage/app/media/npa/5a1fe82a9c95d.pdf.

8. Остапчук O. Є. Самопроектування як засіб професійної самореалізації майбутнього учителя. URL: www.nbuv.gov.ua/ portal/soc_gum/Npdntu_pps/2009_4/ostapchuk.pdf.

9. Пассов Е. И. и др. Мастерство и личность учителя: На примере преподавания иностранного языка. Москва : Флинта: Наука, 2001. 240 с.

10. Профільне навчання: досвід упровадження, інноваційні технології / упор. Л. Ф. Пашко, О. П. Коваленко, Л. І. Симоненко. Полтава : ПОІППО, 2008. 196 с.

11. Пуховська Л. П. Сучасні дослідження в галузі педагогічної освіти у країнах західної Європи. Неперервна професійна освіта: проблеми, пошуки, перспективи : монографія / за ред. І. А. Зязюна. Київ : Віпол, 2000. С. 565-589.

12. Формування змісту профільного навчання: теоретико-методологічний аспект : колективна монографія / авт. кол. : Г. О. Васьківська, В. І. Кизенко, С. В. Косянчук, О. В. Барановська та ін. ; за наук. ред. Г. О. Васьківської. Київ : КОНВІ ПРІНТ, 2018. $260 \mathrm{c}$.

13. Чистякова С. Н., Лернер П. С. Профильное обучение и новые условия подготовки. Школьные технологии. 2002. № 1. C. 101-108.

\section{References:}

1. Bidiuk N. M. (2011) Orhanizatsiino-dydaktychni zasady profesiinoi pidhotovky maibutnikh uchyteliv starshoi shkoly SShA. [Organizational and didactic principles of professional training of future teachers of high school in the United States] Naukovyi visnyk Uzhhorodskoho natsionalnoho universytetu. Seriia "Pedahohika, sotsialna robota". Vyp. 21. S. 24-26 [in Ukrainian]

2. Boiko H. (2006) Formuvannia profesiinoi kompetentsii vchyteliv inozemnykh mov pochatkovoi shkoly. [Formation of professional competence of primary school foreign language teachers] URL: http://oldconf.neasmo.org.ua/node/3029 [in Ukrainian]

3. Vitvytska S. S. (2003) Osnovy pedahohiky vyshchoi shkoly: metodychnyi posibnyk dlia studentiv mahistratury [Fundamentals of higher school pedagogy]. Zhytomyr: Zhytomyr. ped. un-t, $232 \mathrm{~s}$.

4. Haluzevyi standart vyshchoi osvity. (2020). [Industry standard of higher education] URL: https://mon.gov.ua/ua/osvita/visha-osvita/naukovo-metodichna-rada-ministerstva-osviti-i-nauki-ukrayini/zatverdzheni-standarti-vishoyi-osviti [in Ukrainian]

5. Haponenko L. P. (2002) Imitatsiino-ihrovyi pidkhid u formuvanni hotovnosti studentiv do inshomovnoho spilkuvannia. [Imitation-game approach in the formation of students' readiness for foreign language communication] Naukovyi visnyk Pivdennoukrainskoho derzhavnoho pedahohichnoho universytetu im. K. D. Ushynskoho. Vyp. 4-5. S. 53-56. [in Ukrainian]

6. Zahalnoievropeiski Rekomendatsii z movnoi osvity: vyvchennia, vykladannia, otsiniuvannia (2003) [Pan-European Recommendations on language education: study, teaching, assessment] / nauk. red. S. Yu. Nikolaieva. Kyiv: Lenvit, 273 s. [in Ukrainian]

7. Kontseptsiia profilnoho navchannia $\mathrm{v}$ starshii shkoli [The concept of specialized education in high school], zatverdzhena nakazom Ministerstva osvity i nauky vid 21.10.2013 r. № 1456. URL: https://mon.gov.ua/storage/app/media/npa/5a1fe82a9c95d.pdf. [in Ukrainian]

8. Ostapchuk O. Ye. Samoproektuvannia yak zasib profesiinoi samorealizatsii maibutnoho uchytelia. [Self-design as a means of professional self-realization of the future teacher] URL: www.nbuv.gov.ua/portal/soc_gum/Npdntu_pps/2009_4/ostapchuk.pdf [in Ukrainian]

9. Passov E. I. i dr. Masterstvo i lichnost uchitelia: Na primere prepodavaniia inostrannogo iazyka. (2001) [Teacher's skill and personality: On the example of teaching a foreign language] Moskva: Flinta: Nauka, $240 \mathrm{~s}$. [in Russian]

10. Pukhovska L. P. Suchasni doslidzhennia v haluzi pedahohichnoi osvity u krainakh zakhidnoi Yevropy. [Modern research in the field of teacher education in Western Europe] Neperervna profesiina osvita: problemy, poshuky, perspektyvy: monohrafiia / za red. I. A. Ziaziuna. Kyiv: Vipol. S. 565-589. [in Ukrainian]

11. Formuvannia zmistu profilnoho navchannia: teoretyko-metodolohichnyi aspect [Formation of the content of profile training: theoretical and methodological aspect]: kol. monohrafiia (2018) / avt. kol.: H. O. Vaskivska, V. I. Kyzenko, S. V. Kosianchuk, O. V. Baranovska, ta in.; za nauk. red. H. O. Vaskivskoi. Kyiv, KONVI PRINT. 260 s. [in Ukrainian]

12. Chistiakova S. N., Lerner P. S. (2002) Profilnoe obuchenie i novye usloviia podgotovki. Shkolnye tekhnologii. [Profile training and new training conditions. School technologies] № 1. S. 101-108. [in Russian]

\section{Yakymenko P. V. Specificity of the English training of future teachers regarding the specialized training of senior pupils}

The article theoretically examines the problem of professional training of future English teachers for specialized training of high school students, which is associated with the reform of the system of higher and general education (the establishment of two educational qualification levels: bachelor's, master's and the introduction of pre-profile and specialized education in basic and high school).

The paper analyzes the theoretical foundations of the professional training of future English teachers for specialized training of high school students. A definitive analysis of the key concepts is made: "preparation", "professional training", "pro- 
fessional training of the future English teacher", "the readiness of the future English teacher for specialized training of high school students". The current state of professional training of future teachers for specialized training of senior pupils in higher educational institutions has been analyzed. Various approaches to the definition of the concept of "professional training" are revealed, the content and basic principles of future English teacher's training are clarified.

The axiological-motivational, cognitive, praxeological, professional-personal, creative and reflexive criteria determined by their indicators, on the basis of which the levels are ascertained, are also separated chemically. As a result of the analysis of philosophical, psychological, pedagogical, methodical literature, the current state of professional training of future English teachers for specialized training of high school students, understanding of the practical pedagogical experience of higher education institutions

The main trends in the field of higher pedagogical foreign language education and the requirements for the level of professional training of a modern English language teacher for specialized training of high school students have been determined. The specifics of the professional training of future teachers have been substantiated, taking into account the traditions and positive experience of organizing the educational process.

Key words: professional training, English teacher, readiness, specialized training. 